\title{
PENERAPAN LESSON STUDY UNTUK MENINGKATKAN PERFORMANSI MENGAJAR DOSEN DALAM PERKULIAHAN NAHWU DI KELAS
}

\author{
Moh. Khasairi \\ moh.khasairi.fs@um.ac.id \\ Universitas Negeri Malang \\ M. Syathibi Nawawi \\ m.syatibi.nawawi.fs@um.ac.id \\ Universitas Negeri Malang \\ Irhamni \\ Irhamni.fs@um.ac.id \\ Universitas Negeri Malang
}

\begin{abstract}
Absract This research aimed at describing the application of Lesson Study to increase lecturer's teacing performance in teaching Nahwu. The researchers used classroom action research in two cycles. The subjects of this research were the students taking Nahwu course with low competence. The result showed that the lecturer model was successful to enhance his patience which he did not recognise before to solve his teaching performance of "difficult" course, i.e. discussing the problem with his colleagues. The observer of this Lesson Study scored 95\% for the success of applying Lesson Study, and $98 \%$ for the positive change of each step done.
\end{abstract}

Keywords: Leson Study; Nahwu; Department of Arabic Literature of UM

\begin{abstract}
Abstrak Tujuan penelitian ini mendeskripsikan penerapan Lesson Study untuk meningkatkan performansi mengajar dosen dalam perkuliahan Nahwu di kelas. Peneliti menggunakan metode penelitian tindakan kelas dengan dua siklus. Subyek penelitian adalah mahasiswa peserta perkuliahan Nahwu yang berkemampuan rendah. Hasil penelitian menunjukkan bahwa dosen model telah berhasil mengembangkan kesadarannya yang tidak terduga sebelumnya, yaitu bersabar untuk mengatasi permasalahan performansi pembelajaran di kelas "sulit", dengan terus berdiskusi dengan kolega. Pengamat dalam Lesson Study ini memberikan angka penilaian 95\% sebagai persentase keberhasilan melaksanakan Lesson Study dan 98\% sebagai persentase perubahan positif setiap langkah pembelajaran yang dilaksanakan.
\end{abstract}

Kata Kunci: Lesson Study; Nahwu; Jurusan Sastra Arab UM. 


\section{PENDAHULUAN}

Pembelajaran bahasa Arab di Indonesia dewasa in telah mengalami perkembangan yang positif. Jika di awal perkembangannya di abad 14 bahasa Arab hanya disadari sebagai bahasa agama Islam maka sekarang bahasa Arab telah dipandang sebagai bahasa internasional yang sejajar dengan bahasa Inggris, Perancis, Jerman dan China. Di awal pertumbuhan Islam di Indonesia bahasa Arab hanya dikenal dan dikenalkan sebagai bahasa Agama yang terisolasi pada lingkungan Islam dan bahkan hanya di lingkungan musalla atau langgar dan masjid yang fungsinya untuk menjalankan ibadah yang harus dilaksanakan dengan menggunakan bahasa Arab. Saat itu image bahasa Arab cukup rendah terutama jika dibandingkan dengan image bahasa Inggris dan bahkan berdampak pada orang yang mempelajarinya. Para pelajar bahasa Arab ada yang menyebutnya "kampungan" dan jauh dari perkembangan. Namun, tidak demikian saat ini bahkan bahasa Arab pada beberapa dasawarsa terakhir ini telah merupakan salah satu bahasa resmi PBB. Jika saat pertumbuhan Islam di Indonesia bahasa Arab hanya diajarkan di lembaga non formal atau informal maka dewasa ini bahasa Arab diajarkan di sekolah-sekolah formal baik lembaga yang berbasis agama (di bawah naungan Kementerian Agama) maupun umum (di bawah naungan kementerian Kementerian Pendidikan dan Kebudayaan, Kementerian Ristek dan Perguruan Tinggi, dan lainnya).

Hasil pembelajaran Bahasa Arab selama ini (di lembaga formal) masih kurang memuaskan. Hal itu seperti diungkapkan Haris (2001) yang mengatakan bahwa penyebabnya adalah pengelolaan pengajaran yang kurang maksimal, mulai dari penyediaan sumber daya manusianya (kualitas pengajar) sampai dengan sumber daya materialnya termasuk di dalamnya persoalan metodologinya. Akibatnya, lebih dari 75\% guru bahasa Arab di sekolahsekolah penyelenggara mata pelajaran bahasa Arab baik sekolah umum maupun sekolah berbasis agama belum memiliki standar ideal sebagai guru bahas Arab. Kondisi buruknya hasil pembelajaran yang 16 tahun lalu diungkapkan Haris masih terjadi saat ini di perguruan tinggi (PT), misalnya mahasiswa yang telah lulus ujian skripsi (2015) masih sering melakukan kesalahan.

Temuan lain tentang pembelajaran bahasa Arab menunjukkan bahwa pembelajaran bahasa Arab masih menghadapi problem yang berkaitan dengan guru, siswa dan media pembelajaran (Muhaiban, 2006). Pengajaran bahasa Arab juga menghadapi problem yang berkaitan dengan proses belajar-mengajar yang cenderung membosankan (Kamaluddin, 2005). Ini artinya dalam rentang tahun (paling tidak) mulai 2001, 2005, 2006 dan 2015 sampai saat ini masih terjadi persoalan dalam pembelajaran bahasa Arab. Kendati peneliti belum mendapatkan data historis persoalan di PT, namun realitas yang terjadi di PT di atas perlu mendapatkan perhatian.

Berdasarkan hasil wawancara, pengamatan dan diskusi mendalam (dalam FORKOM di FS UM, 2015) dapat disimpulkan bahwa pembelajaran bahasa Arab di PT yang menjadi tempat penelitian bahwa mahasiswa yang menguasai tuntutan kurikulum secara tuntas diperkirakan hanya sekitar 30 persen (2015). Sedangkan berdasarkan tes membaca teks gundul, mahasiswa yang menguasai bahasa Arab diperkirakan hanya 20 persen. Seorang perwakilan dari mahasiswa menyampaikan pendapatnya bahwa Nahwu mereka kurang mantap sehingga ketika mengikuti perkuliahan mereka menjadi tertinggal. Bagi mereka, Nahwu merupakan dasar yang menjadi pijakan dalam semua mata kuliah atau perkuliahan. Ini artinya pembelajaran bahasa Arab (dalam hal ini Nahwu) masih memerlukan pembenahan yang serius baik dari sisi pembelajar, sumber daya manusia atau pengajar, kurikulum dan metode pembelajaran. 
Nahwu adalah satu pusat perhatian dalam pembelajaran bahasa Arab, baik yang bersifat produktif maupun reseptif. Karena itu harus mendapat perhatian yang serius. Pernyataan tersebut sejalan dengan permasalahan yang dihadapi oleh mahasiswa seperti yang terungkap dalam wawancara di atas. Untuk meningkatkan kualitas pembelajaran Nahwu sasaran sentral yang mendesak untuk dibenahi antara lain adalah kualitas pembelajaran yang dilakukan dosen.

Pengembangan keprofesionalan dosen harus selalu ditingkatkan, karena peningkatan keprofesionalan dosen akan diikuti oleh peningkatan efektivitas kegiatan belajar mengajar dan secara tidak langsung peningkatan keprofesionalan dosen juga akan berdampak pada peningkatan mutu pendidikan secara luas. Oleh karena itu, Lesson Study diperlukan peranannya.

Lesson Study memungkinkan pengajar untuk: 1) memikirkan dengan cermat mengenai tujuan dari pembelajaran, materi pokok dan bidang studi, 2) mengkaji dan mengembangkan pembelajaran terbaik yang dapat dikembangkan, 3) memperdalam pengetahuan mengenai materi pokok yang diajarkan, 4) memikirkan secara mendalam tujuan jangka panjang yang akan dicapai berkaitan dengan pembelajar, 5) merancang pembelajaran secara kolaboratif, 6) mengkaji secara cermat cara dan proses belajar serta tingkah laku siswa, 7) mengembangkan pengetahuan pedagogis yang kuat/penuh daya, dan melihat hasil pembelajaran sendiri melalui mata pembelajar dan kolega (bandingkan dengan Susilo, 2005, Hendayana, 2007, dan Salma, 2008).

Temuan Gomes (2015) menyatakan bahwa Lesson Study memperkuat gerakan teoritis praktis, refleksinya tindakan untuk menemukan kepercayaan, kebiasaan, sikap, dan emosi implisit yang mendasari praktik tersebut, dan eksperimen teori baru untuk membentuk kebiasaan, keyakinan, sikap, dan emosi baru yang mendukung pengembangan bentuk pengajaran baru. Lebih lanjut mereka merekomendasikan bahwa Lesson Study sebagai metode pelatihan guru yang dapat memperbaiki praktik melalui rekonstruksi pemikiran praktis mereka yang terlibat.

Berangkat dari kondisi faktual di atas, tampaknya aspek kualitas dosen menjadi salah satu hal yang mendesak untuk segera dicarikan penyelesaiannya. Strategi yang dipandang efektif untuk meningkatkan profesionalisme dosen bahasa Arab (dosen Nahwu dalam hal ini) adalah melalui penerapan model Lesson Study dalam bentuk kegiatan Penelitian Tindakan kelas. Secara detail judul penelitiannya adalah Penerapan Lesson Study untuk Meningkatkan Performansi Mengajar Dosen dalam Perkuliahan Nahwu di Kelas Semester Gasal 2015/2016 di Jurusan Sastra Arab UM.

Dari sini diharapkan para pengajar bahasa Arab di Perguruan Tinggi akan mampu memperbaiki dan meningkatkan pola pembelajarannya serta mampu melakukan inovasiinovasi baru yang efektif dalam PBM sehingga pada akhirnya akan menghasilkan peningkatan kualitas pembelajaran bahasa Arab, khususnya Nahwu dalam penelitian ini.

Lesson Study yakni suatu model (pola) pembinaan profesi pendidik melalui pengkajian (studi) pembelajaran secara kolaboratif dan berkelanjutan berlandaskan prinsip-prinsip kolegalitas dan mutual learning untuk membangun komunitas belajar (Susilo, 2005 dan Hendayana, 2007). Sedangkan PTK adalah pengembangan dari penelitian tindakan (PT) yang tidak hanya difokuskan pada kegiatan di kelas. PT dilakukan untuk mengintervensi masyarakat dan perubahannya ke arah yang dikehendaki.

Dilihat dari kata yang membangun istilah PTK tidaklah salah bila PTK dimengerti sebagai penelitian yang di dalamnya terdapat tindakan yang terjadi dalam kaitannya dengan kelas. Di dalam kelas seorang peneliti dapat memfokuskan perhatiannya pada guru, murid, 
materi, atau lingkungan. Persoalan-persoalan yang berkaitan dengan keempat hal tersebut begitu juga hubungan yang dihasilkan oleh keempat hal itu dapat menjadi problem yang patut dijadikan permasalahan penelitian tindakan.

Tujuan utama PTK adalah melakukan suatu perubahan di mana hal itu tersirat dalam kata action (tindakan) dan berupaya lebih memahami dirinya sendiri dan subjek penelitiannya (siswa) dalam pembelajaran dan yang terkait dengan pembelajaran itu sendiri, misalnya materi, media, lingkungan dan sebagainya namun demikian adanya perubahan dalam diri subjek merupakan tujuan utamanya. Dengan demikian hasil PTK adalah perubahan yang terjadi pada diri subjek dan pemahaman yang mendalam terhadap siapapun yang terlibat di dalamnya.

\section{METODE}

Jenis penelitian yang dilaksanakan ini adalah jenis penelitian tindakan kelas (Classroom Action Research). Menurut Wiriatmadja (dalam Ristianah, 2007) penelitian tindakan kelas adalah bagaimana sekelompok guru dapat mengorganisasikan kondisi praktik pembelajaran mereka, dan belajar dari pengalaman mereka sendiri. Penelitian tindakan kelas dicobakan sebagai gagasan perbaikan dalam praktik pembelajaran dan melihat pengaruh yang nyata dari upaya tersebut.

Penelitian tindakan kelas dilakukan melalui beberapa siklus yang setiap siklus terdiri atas empat tahap yaitu: (1) perencanaan, (2) pelaksanaan, (3) pengamatan, dan (4) refleksi. Penelitian ini dilaksanakan dalam perkuliahan Nahwu di jurusan sastra Arab UM. Subjek penelitian ini adalah dosen yang mengajarkan Nahwu dan mereka yang terlibat dalam Lesson Study yaitu Drs. Moh. Khasairi, M.Pd., Drs. Mohammad Syathibi Nawawi, M.Pd., dan Dr. Irhamni, M.Pd.

Data yang ada dalam penelitian adalah data tentang penerapan Lesson Study dan peningkatan performansi dosen dalam mengajar Nahwu. Sedangkan yang menjadi sumber datanya adalah aktivitas pembelajaran Nahwu yang didesain dengan model pembelajaran Lesson Study. Untuk memastikan peningkatan performansi dosen dalam mengajar dilakukan pembandingan antara introspeksi dan interpretasi terhadap tindakan yang telah dilakukan oleh dosen sebelum dilakukan Lesson Study dan setelah Lesson Study.

Data tentang performansi awal diperoleh melalui penggalian interpretif terhadap apa yang pernah dilakukan oleh masing-masing dosen yang terlibat dalam Lesson Study. Sedangkan data yang berkaitan dengan performansi setelah Lesson Study diambil dari hasil observasi, wawancara, dan hasil diskusi. Sehubungan dengan itu maka data dikumpulkan dengan teknik observasi dan wawancara. Dengan demikian, instrumen yang digunakan dalam penelitian ini ada dua. Instrumen pertama adalah peneliti itu sendiri karena data yang digali adalah data verbal dan yang kedua adalah panduan observasi dan wawancara yang memuat data kuantitatif.

\section{HASIL DAN PEMBAHASAN}

Hasil penelitian ini dipaparkan dalam bentuk siklus-siklus PTK berikut.

\section{Tahap Perencanaan}

Pada tahap ini dilakukan kegiatan yaitu melakukan pertemuan awal dengan dosen Nahwu dan dosen yang akan terlibat dalam Lesson Study lalu menyampaikan hal-hal mengenai 
perencanaan tindakan dalam konteks Lesson Study yang akan dilaksanakan. Pada tahap ini tim peneliti melakukan semacam kesepakatan berdasarkan pengetahuan masing-masing dengan menentukan dosen yang bertindak sebagai pengajar dan yang bertindak sebagai pengamat. Disepakati, yang menjadi model adalah dosen pengampu mata kuliah Nahwu di kelas subjek penelitian yang diobservasi oleh dua orang dosen dan seorang mahasiswa. Setelah itu tim peneliti mengembangkan rencana, dan dalam tahap ini pokok bahasannya adalah $\mathrm{badl}$. Setelah itu tim peneliti menyiapkan format observasi perkuliahan dalam Lesson Study dan lembar observasi perkuliahan dalam Lesson Study yang keduanya digunakan untuk mengamati proses pembelajaran baik dalam penyampaian materi maupun dalam penerapan teknik Lesson Study. Lembar pertama berkaitan dengan persoalan pembelajaran mahasiswa dan upaya yang dilakukan dosen untuk menyelesaikan masalah dan lembar kedua berkaitan dengan penerapan Lesson Study dalam praktek pembelajaran yang berkaitan dengan kegiatan awal, kegiatan inti, dan kegiatan penutup.

\section{Tahap Pelaksanaan Tindakan}

Tahap pelaksanaan tindakan dilaksanakan dalam dua kali pertemuan yang meliputi: pertemuan ke (1) penyajian materi badl dan penerapan teknik Lesson Study dan (2) evaluasi pembelajaran tentang badl.

\section{Pertemuan Pertama}

Pada pertemuan pertama ini dosen menyajikan materi badl dalam bahasa Indonesia dan bahasa Arab. Pada tahap penyajian dosen membacakan materi dalam bahasa Arab dan kemudian seluruh mahasiswa mengikuti, memberikan kesempatan kepada mahasiswa untuk bertanya konsep yang sulit disertai dengan contoh-contoh dan begitu seterusnya. Kemudian dilakukan diskusi kelas dan setelah selesai dilakukan tanya jawab oleh dosen untuk mengetahui penguasaan mahasiswa terhdap materi yang disampaikan. Dalam proses pembelajarannya dosen menerapkan teknik pembelajaran Lesson Study yang diamati oleh dosen yang ikut terlibat di dalamnya. Sebelum memulai kegiatan Lesson Study, dosen yang terlibat dalam mendiskusikan strategi dan sesuatu yang diperlukan. Posisi pengamat diatur sedemikian rupa untuk bisa menjalankan tugasnya dengan baik.

\section{Pertemuan Kedua}

Pada pertemuan kedua ini dosen mengajak mahasiswa mengulang kembali membaca teks/materi badl yang telah disampaikan pada pertemuan sebelumnya. Setelah selesai pada kegiatan membaca nyaring dosen memberi tugas/kuis kepada mahasiswa sebagai bahan evaluasi. Dan kemudian dosen memberikan penghargaan kepada mahasiswa yang telah berhasil mengumpulkan tugasnya paling cepat dan paling benar, mereka akan mendapatkan reward yang telah disepakati sebelumnya. Tahap terakhir, dosen bersama mahasiswa membuat kesepakatan pelajaran tentang badl.

\section{Tahap Pengamatan}

Observasi dilakukan selama proses pembelajaran berlangsung. Pada tahap ini dilakukan observasi terhadap aktivitas pengajaran dan pembelajaran oleh dosen pengamat. Mereka memanfaatkan format atau instrumen pengamatan yang telah dikembangkan dalam tahap persiapan. 
Hasil pengamatannya (hanya sebagai contoh kecil) dapat divisualkan berikut:

Berdasarkan pengamatan yang dilakukan ada temuan-temuan yang bisa dianggap sebagai masalah dalam pembelajaran, yang berkaitan dengan performansi dosen, yaitu: (1) Mahasiswa tidak fokus dan main hp, (2) Mahasiswa tidak membawa buku ajar, (3) Latihan kurang memadahi dan kurang relevan dengan yang diperlukan mahasiswa, (4) Diskusi antar dosen peserta Lesson Study pasca pembelajaran belum maksimal, (5) Fokus diskusi perlu difokuskan pada performansi dosen, (6) Dosen menuntun mahasiswa mengerjakan tugas, (7) Kontrol terhadap mahasiswa kurang ketat, sebagian mahasiswa tidak membawa buku teks, (8) Belum ada tindakan yang pas untuk mengatasi perilaku negatif mahasiswa, (9) Interaksi pembelajaran belum mampu mendongkrak intensitas belajar yang maksimal, (10) Variasi tindakan pembelajaran yang mengarah pada efektivitas pembelajaran mahasiswa perlu ditingkatkan, (11) Kurang ada materi yang bersifat memberi tantangan yang segar, bukan sekedar tugas yang diambil dari buku akan tetapi semacam spontanitas kreatif dari dosen, (12) Latihan yang berkembang dalam pembelajaran lebih bersifat responsif terhadap buku ajar. Hal ini cukup memicu terjadinya kebosanan dan munculnya jawaban minimalis dari mahasiswa, (13) Diskusi-diskusi menarik yang lebih menantang sesuai dengan usia mahasiswa yang mengarah pada semacam perdebatan serius tidak muncul dari inisiatif dosen, (14) Dosen lebih bersifat berpusat pada teks (text centered), dan (15) Dosen hampir selalu di depan kelas pada posisi yang stagnan, jarak antara dosen dan para mahasiswanya secara ruang dan tempat cukup jauh kecuali beberapa mahasiswa yang secara kebetulan duduk di baris depan.

Berdasarkan masalah-masalah tersebut, tim berupaya mencari metode pembelajaran yang bisa mengakomodir penyelesaiannya, sehingga ditemukan metode yang secara teoritis cocok seperti ditemukan pada tahap refleksi berikut, yaitu metode transle self-review seperti yang dijelaskan kemudian pada Tahap Refleksi.

\section{Tahap Refleksi}

Refleksi merupakam tahap dalam penelitian tindakan kelas yang penting dalam kaitannya dengan kegiatan menentukan tindakan lanjutan atau perbaikan tindakan yang harus dilakukan. Berdasarkan data yang diperoleh dari tindakan siklus 1 maka data diolah atau dianalisis. Peneliti bersama pengamat merenungkan hasil tindakan siklus 1 sebagai bahan pertimbangan apakah siklus sudah mencapai kriteria atau tidak. Hasilnya, penerapan Lesson Study sudah sesuai dengan kriteria, 80\% positif dan 90\% dosen melakukan perubahan dalam performansi di saat membelajarkan mahasiswa, namun berdasarkan kepuasan hasil pembelajarannya khusus untuk kelas A ini perlu diadakan perbaikan dan penambahan kesempatan mengulang hasil pembelajaran. Perbaikannya adalah pengguanaan metode penerjemahan bahasa Indonesia ke dalam bahasa Arab. Pembelajaran semacam ini mempunyai kelebihan untuk dikondisikan sesuai kebutuhan mahasiswa, yaitu meningkatkan pengulangan pemahaman dan latihan menggunakan badl dalam kegiatan berbahasa yang bersifat produktif. Dengan kegiatan yang bersifat produktif ini mahasiswa akan lebih tertantang dalam belajarnya. Sementara soal latihan yang ada dalam buku teks dan yang terjadi dalam kelas lebih bersifat sesaat dan kurang memberikan tantangan pada mahasiswa. Bagi mereka tantangan sangat penting untuk meningkatkan semangat belajar. Dengan semangat yang kuat maka mereka tidak mudah menyerah dalam belajarnya, baik yang berkaitan dengan pemahaman badl maupun dalam memproduksi kalimat dengan unsur badl. Kegiatan penerjemahan yang diusulkan tersebut bisa dimaksimalkan lagi tantangannya jika 
menggunakan merode translate-review, di mana mahasiswa harus menerjemahkan sendiri, mencari kesalahan sendiri dan memperbaiki kesalahannya sendiri. Metode ini telah terbukti mempunyai manfaat yang besar bagi pembelajaran dasar-dasar ketrampilan berbahasa, terutama Nahwu atau kaidah bahasa Arab dan metode ini cukup menarik bagi mahasiswa (Irhamni dan Maksum, 2014), yaitu:

Dari sisi namaya metode self-review ini merupakan metode pembelajaran yang dimulai dengan kegiatan menerjemahkan kemudian diikuti dengan kegiatan mereview secara mandiri hasil terjemahan yang telah dihasilkan. Di Pesantren Daarul Hijrah, dengan metode ini para santri yang sedang belajar bahasa Arab diberi tugas menerjemahkan teks berbahasa Indonesia ke dalam bahasa Arab. Tugas santri berikutnya adalah mengoreksi sendiri hasil terjemahannya. Asumsi tentang terjemahan sebagai basis pembelajaran menggambarkan bahwa penerjemahan merupakan kegiatan produktif dalam berbahasa yang melibatkan faktor linguistik dan ekstralinguistik. Faktor linguistik yang dimaksud adalah unsur-unsur gramatika dan kaidah, dan faktor ekstralinguistik adalah jenis-jenis teks serta isi yang diterjemahkan. Dalam kegiatan penerjemahan ini terdapat kegiatan pembandingan bahasa sumber ( $\mathrm{BSu}$ ) yang berupa teks bahasa Indonesia dengan bahasa Sasaran (BSa) yang berupa teks bahasa Arab. Sedangkan pentingnya self-review didasarkan pada asumsi bahwa kemandirian merupakan sikap dasar yang menjadi salah satu penentu keberhasilan pembelajar. Peran guru lebih sebagai fasilitator.

Dengan kegiatan terjemahan yang demikian maka terjadi semacam keterbukaan bagi dosen Nahwu untuk berkenan melakukan perubahan dan melihat potensi metode yang bisa digunakan untuk meningkatkan proses pembelajaran. Peningkatan performansi dosen tidak hanya terletak pada perubahan tampilan fisik namun juga pada perubahan wawasan dan pemikiran untuk bisa lebih kritis melihat hal yang selama ini "cukup diabaikan" dan bahkan dijauhi, yaitu penggunaan penerjemahan sebagai media pembelajaran bahasa asing.

Metode terjemahan dengan model self-review yang diterapkan dalam Lesson Study ini merupakan pertama kalinya dalam pembelajaran Nahwu. Menurut hemat penulis Lesson Studi merupakan model yang sangat mengedepankan kerja sama dan kolaborasi antarpengajar. Dengan demikian dosen yang menerapkan model ini akan merasa nyaman dalam melaksanakan tugasnya. Hal ini sejalan dengan temuan penelitian Gero (2015) yang menunjukkan adanya hubungan yang signifikan antara tingkat kenyamanan guru dengan kolaborasi, observasi pelajaran, kritik pelajaran, dan dukungan mereka untuk Lesson Study. Kondisi yang demikian mengisyaratkan ketercapaian tujuan pembelajaran akan lebih maksimal.

Dalam pembelajaran Bahasa, metode qawaaid dan terjemah merupakan metode yang paling lama digunakan bahkan sampai sekarang masih bertahan. Beragam tanggapan selalu mengemuka mengenai penerapan metode ini, baik yang positif maupun negative. Studi kasus yang dilakukan oleh Kelly dan Bruen (2015) dalam bentuk wawancara kualitatif dengan enam dosen di Jepang dan enam dosen di Jerman secara bersamaan dengan ulasan dokumentasi terkait, hasilnya menunjukkan adanya dukungan yang luas di lapangan untuk penggunaan terjemahan dalam pengajaran Bahasa.

\section{Siklus 2}

Seperti juga pada siklus 1, siklus 2 ini diawali dengan perencanaan, dilanjutkan dengan implementasi, lalu observasi dan refleksi. 


\section{Tahap Perencanaan}

Pada tahap ini dilakukan kegiatan yaitu melakukan pertemuan awal dengan dosen Nahwu dan dosen yang akan terlibat dalam Lesson Study lalu menyampaikan hal-hal mengenai perencanaan penelitian yang dilaksanakan. Pada tahap ini tim peneliti melakukan semacam kesepakatan berdasarkan pengetahuan masing-masing dengan menentukan dosen yang bertindak sebagai pengajar dan yang bertindak sebagai pengamat. Disepakati, yang menjadi model adalah dosen pengampu mata kuliah Nahwu di kelas subjek penelitian yang diobservasi oleh dua dosen dan satu mahasiswa. Setelah itu tim peneliti mengembangkan rencana pembelajaran. Dalam tahap ini pokok bahasannya adalah ya' nisbah. Setelah itu tim peneliti menyiapkan format observasi perkuliahan dalam Lesson Study dan lembar observasi perkuliahan dalam Lesson Study yang keduanya akan digunakan untuk mengamati proses pembelajaran baik dalam penyampaian materi maupun dalam penerapan teknik Lesson Study. Lembar pertama berkaitan dengan persoalan pembelajaran mahasiswa dan upaya yang dilakukan dosen untuk menyelesaikan masalah dan lembar kedua berkaitan dengan penerapan Lesson Study dalam praktek pembelajaran yang berkaitan dengan kegiatan awal, kegiatan inti dan kegiatan penutup. Perencanaan pada siklus 2 ini mirip dengan perencanaan pada siklus 1 akan tetapi memasukkan metode translate self-review dalam perkuliahan ini. Ini sebagai salah satu kesepakatan yang diambil dalam refleksi siklus 1 .

\section{Tahap Pelaksanaan Tindakan}

Dalam pelaksanaan tindakan siklus 2 ini dosen telah melakukan amanat hasil refleksi pada siklus 1. Dosen telah mengubah penampilannya sesuai dengan skenario Lesson Study yang berorientasi pada pengembangan performansi dosen dalam melaksanakan pembelajaran Nahwu. Dosen Nahwu ini merupakan dosen yang sejak awal berniat menjadi model pembelajaran Lesson Study yang ingin memperbaiki hasil pembelajaran Nahwu dengan jalan mengembangkan performansinya dalam pembelajaran. Dia menyetujui translate self-review sebagai salah satu metode yang diterapkan dalam pembelajarannya. Hal ini untuk menjawab berbagai permasalahan yang terjadi pada pembelajaran siklus 1 .

\section{Tahap Pengamatan}

Berdasarkan pengamatan yang tim lakukan, bisa disimpulkan bahwa dosen Nahwu pada siklus 2 ini telah melakukan pengembangan dan peningkatan performansinya dalam melaksanakan pembelajaran Nahwu sesuai tuntutan perubahan yang harus diambil untuk menyelesaikan persoalan yang ditemukan dalam siklus 1. Perubahan-perubahan dan pengembangan performansi pembelajaran Nahwu yang dimaksud adalah sebagai berikut:

1. Pada siklus 1 mahasiswa tidak fokus dan main hp, pada siklus 2 dosen berhasil mengalihkan perhatian mereka pada kegiatan pembelajaran.

2. Pada siklus 1 mahasiswa tidak membawa buku ajar, pada siklus 2 dosen sudah berupaya memperhatikan mereka sehingga membawa buku ajar.

3. Pada siklus 1 latihan kurang memadahi dan kurang relevan dengan yang diperlukan mahasiswa, pada siklus 2 dosen telah menampilkan latihan yang memadahi dan lebih menantang sesuai alam psikologis mahasiswa.

4. Pada siklus 1 diskusi antar dosen peserta Lesson Study pasca pembelajaran belum maksimal, pada siklus 2 diskusi antar dosen dan tim menjadi intensif.

5. Pada siklus 1 dosen menuntun mahasiswa mengerjakan tugas, pada siklus 2 dosen memberi dorongan pada mahasiswa untuk bisa. 
6. Pada siklus 1 kontrol terhadap mahasiswa kurang ketat, sebagian mahasiswa tidak membawa buku teks, pada siklus 2 dosen telah melakukan upaya persuasif sehingga tidak ada lagi mahasiswa yang tidak membawa buku teks.

7. Pada siklus 1 belum ada tindakan yang pas untuk mengatasi perilaku negatif mahasiswa, pada siklus 2 dosen telah melakukan upaya untuk mengatasi hal tersebut, misalnya ketika ada mahasiswa yang bermain dengan $\mathrm{hp}$, dosen telah berhasil mengalihkan perhatian mereka pada pelajaran.

8. Pada siklus 1 interaksi pembelajaran belum mampu mendongkrak intensitas belajar yang maksimal, pada siklus 2 dosen telah berupaya mencari model-model interaksi yang lebih bersifat situasional; kadang-kadang diselingi dengan humor.

9. Pada siklus 1 variasi tindakan pembelajaran yang mengarah pada efektivitas pembelajaran mahasiswa perlu ditingkatkan, pada siklus 2 dosen mampu menerapkan tindakan pembelajaran secara efektif, mesilnya pelibatan mahasiswa pada pemecahan masalah yang bersifat umum.

10. Pada siklus 1 kurang ada materi yang bersifat memberi tantangan yang segar, bukan sekedar tugas yang diambil dari buku akan tetapu semacam spontanitas kreatif dari dosen, pada siklus 2 dosen telah mencoba menyelipkan materi yang diambil dari luar buku teks.

11. Pada siklus 1 latihan yang berkembang dalam pembelajaran lebih bersifat responsif terhadap buku ajar. Hal ini cukup memicu terjadinya kebosanan dan munculnya jawaban minimalis dari mahasiswa, pada siklus 2 dosen telah membuat semacam soal-soal atau spontanitas yang berkembang dari mahasiswa itu sendiri, misalnya dosen menindaklanjuti permasalahan yang berkembang dari mahasiswa.

12. Pada siklus 1 diskusi-diskusi menarik yang lebih menantang sesuai dengan usia mahasiswa yang mengarah pada semacam perdebatan serius tidak muncul dari inisiatif dosen, pada siklus 2 dosen telah "melibatkan" emosi mahasiswa dengan cara mengemukakan tantangan dengan ungkapan tertentu, misalnya siapa yang tahu, di saat kelas kelihatannya belum mengetahui. Dari pertanyaan tersebut diskusi spontan antarmahasiswa walaupun tidak harus menemukan jawabannya saat itu.

13. Pada siklus 1 dosen lebih bersifat berpusat pada teks (text centered), pada siklus 2 dosen telah mengelaborasi interaksinya meluas di luar teks.

14. Pada siklus 1 dosen hampir selalu di depan kelas pada posisi yang stagnan, jarak antara dosen dan para mahasiswanya secara ruang dan tempat cukup jauh kecuali beberapa mahasiswa yang secara kebetulan duduk di baris depan, pada siklus 2 dosen telah bergerak merata secara intensif pada tempat duduk mahasiswa.

Itulah perubahan-perubahan yang terjadi pada performansi dosen dengan penerapan Lesson Study ini. Hal ini sesuai dengan manfaat Lesson Study yaitu memperbaiki performansi dosen dalam mengajar.

\section{Refleksi}

Refleksi yang dilakukan di akhir perkuliahan mendiskusikan perubahan-perubahan performansi dan berupaya mengangkakan perubahan positif yang terjadi pada pembelajaran Nahwu oleh dosen model. Dalam refleksi itu diperoleh kesimpulan bahwa siklus 2 ini sudah cukup untuk menjawab masalah penelitian yaitu tentang penerapan Lesson Study dan hasilnya bagi pengembangan atau perubahan positif performansi dosen dalam melaksanakan 
pembelajaran Nahwu di kelas yang "berat", di mana kemampuan mahasiswa berada di bawah rata-rata kelas yang lain. Mereka ini secara empiris belum mempunyai modal yang cukup untuk mengikuti perkuliahan Nahwu. Karena itu performansi yang ditampilkan oleh dosen, sejak awal telah dilandasi oleh upaya ekstra maksimal dalam menangani mahasiswa kelas subjek penelitian ini. Hasilnya, dosen model telah melakukan perubahan positif yang hampir tak terduga dalam melaksanakan pembelajaran Nahwu di kelas bawah ini. Pengamat dalam Lesson Study ini memberikan angka penilaian 95\% sebagai persentase keberhasilan melaksanakan Lesson Study dan 98\% sebagai persentase perubahan positif setiap langkah pembelajaran yang dilaksanakan.

Peningkatan performansi dosen dalam melaksanakan pembelajaran Nahwu merupakan salah satu hasil dari penerapan Lesson Study melalui PTK. Peningkatan semacam itu nampaknya sudah menjadi optimisme yang terekam dalam diskusi-diskusi tentang Lesson Study dan PTK. Aspek positif dari Lesson Study tersebut senada dengan optimisme yang tersirat dalam pandangan Lewis (2002) yang menyebutkan:

"Lesson Study is a simple idea. If you want to improve instruction, what could be more obvious than collaborating with fellow teachers to plan, observe, and reflect on lessons? While it may be a simple idea, Lesson Study is a complex process, supported by collaborative goal setting, careful data collection on student learning, and protocoLesson Study that enable productive discussion of difficult issues".

Catatan yang bisa diberikan untuk kutipan tersebut berkaitan dengan peningkatan performansi dosen dalam penelitian ini adalah adanya keharusan mengadakan diskusi antar dosen yang terlibat dalam Lesson Study untuk memecahkan masalah yang sedang dihadapi, meningkatkan aspek positif yang sudah berkembang dan mengkritisi sesuatu yang seolah terjadi dengan sendirinya.

Temuan tersebut menambah alternatif upaya peningkatan efektivitas pembelajaran Nahwu. Dengan penerapan translate self-review berarti dosen menerapkan strategi yang selama ini belum pernah diterapkannya dalam pembelajaran Nahwu. Bagaimanapun disadari bahwa efektivitas pembelajaran Nahwu tidak hanya ditentukan oleh strategi pembelajaran yang diterapkan, tetapi juga pemilihan materi yang tepat. Temuan penelitian Lin dan Lee (2015) yang menyatakan bahwa pembelajaran berbasis data merupakan pendekatan yang inovatif dan menarik dalam pengajaran tata bahasa (Nahwu). Komponen lain yang juga berkontribusi terhadap efektivitas pembelajaran gramatika adalah ekspresi perasaan dosen (guru) yang memposisikan wacana tata bahasa sebagai inspirasi, menarik, dan memberdayakan (Watson, 2012).

\section{SIMPULAN}

Secara garis besar, hasil penelitian ini dapat disimpulkan bahwa penerapan Lesson Study dalam pembelajaran Nahwu di kelas berkemampuan rendah ini berjalan melalui 2 siklus yang pada siklus pertama refleksinya menghasilkan sejumlah permasalahan yang perlu diselesaikan dalam kaitannya dengan tujuan Lesson Study, yaitu perbaikan dan pengembangan performansi dosen. Pada siklus kedua, refleksinya menyimpulkan bahwa dosen model telah berhasil melakukan perubahan dan perkembangan positif dalam melaksanakan pembelajaran di kelas "sulit" ini (pengakuan dosen pengampu mata kuliah kebahasaan di kelas subjek penelitian ini).

Kesimpulan berikutnya, dosen model telah berhasil mengembangkan kesadarannya yang tidak terduga sebelumnya, yaitu bersabar untuk mengatasi permasalahan performansi 
pembelajaran di kelas "sulit", dengan terus berdiskusi denga kolega. Ternyata Lesson Study mampu membuka kesadaran di saat orang mendapati kebuntuan dan mengalami kejenuhan. Pengamat dalam Lesson Study ini memberikan angka penilaian 95\% sebagai prosentase keberhasilan melaksanakan Lesson Study dan 98\% sebagai prosentase perubahan positif setiap langkah pembelajaran yang dilaksanakan.

Lesson Study bisa menjadi harapan bagi para pengajar yang sedang mengalami kesulitan pembelajaran. Hal-hal yang semula tidak mungkin dilakukan karena hambatan berat yang berkaitan dengan subjek pembelajaran (mahasiswa dalam hal ini) bisa dilakukan dengan bantuan motivasi dari kolega atau orang lain. Untuk memaksimalkan efek Lesson Study pada perbaikan dan pengembangan performansi pembelajaran, maka perlu dicoba yang menjadi pengamat tidak hanya dari kalangan yang sama (dosen) akan tetapi bisa dari kalangan lain yang relevan dan berkepentingan pada kegiatan pembelajaran dan perbaikan mutu pendidikan pada umumnya misalnya motivator, psikolog, orang tua, ahli kurikulum dan sebagainya. Kebersamaan mereka yang beragam itu dalam mengamati dan mendiskusikan fenomena performansi dosen dan pembelajaran pada umumnya akan menghasilkan pemikiran-pemikiran yang segar dan berguna.

\section{DAFTAR RUJUKAN}

Gero, G. 2015. The Prospects of Lesson Study in The US, Teacher Support and Comfort Within a District Culture Of Control. Emerald Insight International Journal for Lesson and Learning Studies. 4 (1), hal. 7-25

Gómez, E.S, María J. S. N, Angel I. P.G, Noemi P.T. 2015 Lesson Study and the Development of Teacher's Competences, From Practical Knowledge to Practical Thinking. Emerald Insight International Journal for Lesson and Learning Studies. 4. (3). Hal. 209-223.

Haris, A. 2001. Study Kontrastif Bahasa Arab dan Bahasa Indonesia Pada Tataran Sintaksis. Laporan Penelitian. Fakultas Tarbiyah Universitas Muhammadiyah Malang.

Hendayana, S. 2007. Lesson Study (Suatu Strategi untuk Meningkatkan Keprofesionalan Pendidik - Pengalaman IMSTEP-JICA). Bandung: UPI Press.

Irhamni, Maksum, A. 2004. Metode Translate Self-Review Karya Kyai Rahmat Al-Arifin Muhammad Ibn Ma'ruf. Malang: Malak.

Kamaluddin. 2005. Inovasi Pembelajaran dalam PBM Bahasa Arab. Makalah Pelatihan.

Kelly, N., Jennifer, B. 2015. Translation as a Pedagogical Tool in the Foreign Language Classroom: A Qualitative Study of Attitudes and Behaviours. Language Teaching Research Vol. 19 (2) 150-168

Lewis, Catherine C. 2002. Lesson Study: A Handbook of Teacher-Led Instructional Change. Philadelphia, PA: Research for Better School, Inc.

Lin, Ming Huei dan Lee, Jia-Ying. 2015. Data-driven Learning: Changing the Teaching of Grammar in EFL Classes. ELT Journal Volume 69/3 July. hal. 264--274

Muhaiban. 2006. Al-lughah al-'Arabiyyah fi Indunisiya: Dirasah Ta'liliyyah 'an Tatawwuratiha wa Musykilat Ta'limiha. Jurnal Studia Islamika UIN Sunan Kalijaga Yogyakarta, Vol. 13 (1) hal 35-45

Ristianah, N. 2007. Penerapan Model Pembelajaran Model Teams Games Tournament (TGT) untuk Meningkatkan Hasil Belajar Akuntansi Siswa Kelas X-A Program Keahlian Akuntansi SMK Shalahuddin Malang. Malang: Fakultas Teknik UM. 
Salma, S. 2008. Membentuk Guru Profesional Melalui Lesson Study. Harian Jawa Pos. Jawa Pos edisi 10 Januari 2008.

Susilo, H. 2005. Lesson Study: Apa dan Mengapa? Makalah seminar dan workshop. Malang. Makalah tidak diterbitkan.

Watson, A. 2012. Navigating 'the pit of doom': Affective responses to teaching 'grammar'. English in Education 46 (1) hal. 21-37. 